\title{
The Impact of Marine Water on Different Types of Coarse Aggregate of Geopolymer Concrete
}

\author{
Shimaa Younis Megahed', Abolwafa Mohamad Elthakeb², Walid Alsayed Mohamed³, \\ Mohammed Taha Nooman', Walid Hessian Soufy ${ }^{5}$
}

${ }^{1}$ Fayoum Future Institute, Fayoum, Egypt

${ }^{2}$ Department of Reinforced Concrete, Faculty of Engineering, Al-Azhar University, Cairo, Egypt

${ }^{3}$ Department of Irrigation and Hydraulics, Faculty of Engineering, Al-Azhar University, Cairo, Egypt

${ }^{4}$ Department of Properties and Strength of Material Civil Engineering, Faculty of Engineering, Al-Azhar University, Cairo, Egypt

${ }^{5}$ Housing and Building National Research Center (HBRC), Cairo, Egypt

Email: waleed346666@hotmai

How to cite this paper: Megahed, S.Y., Elthakeb, A.M., Mohamed, W.A., Nooman, M.T. and Soufy, W.H. (2019) The Impact of Marine Water on Different Types of Coarse Aggregate of Geopolymer Concrete. Journal of Minerals and Materials Characterization and Engineering, 7, 330-353. https://doi.org/10.4236/jmmce.2019.75023

Received: July 31, 2019

Accepted: September 23, 2019

Published: September 26, 2019

Copyright $\odot 2019$ by author(s) and Scientific Research Publishing Inc. This work is licensed under the Creative Commons Attribution International License (CC BY 4.0).

http://creativecommons.org/licenses/by/4.0/

\begin{abstract}
This research studies the impact of different types of coarse aggregate on the behavior of geopolymer concrete based on both fly ash (FA) and ground granulated blast furnace slag (GGBFS) in different marine environments. Aiming to solve the problems caused by the construction and demolition waste and the depletion of natural aggregates, in the present study coarse recycled aggregates is used to produce new green concrete with a fly ash-slag based geopolymer. By this examination, the research seeks to improve the quality and productivity of concrete used in construction and hydraulic projects. For this research, four mixtures containing different types of coarse aggregate in two different water environments were used. The utilized mixtures contained natural aggregate concrete (NAC) such as basalt and crushed marble. Also, recycled coarse aggregate concrete (RAC), which totally replaced natural aggregate, was presented in this paper such as crushed concrete and crushed ceramic. For this study, in the sieve analysis; specific and unit weights, was recorded. Furthermore, the mechanical properties were determined, using a compressive test that was conducted on the 7 th, 28th, 56th and 90th days at different water environments; potable water (PW) and sea water (SW). Durability test was also performed for total absorption measurement. Results indicated that geopolymer concrete exhibits better strength in marine environments than in those of potable water. Results also showed that crushed marble (CMA) exhibits higher compressive strength and durability.
\end{abstract}

\section{Keywords}

Geopolymer Concrete, Fly Ash, Ground Granulated Blast Furnace Slag 
(GGBFS), Sea Water, Natural Aggregate Concrete, Recycled Concrete

Aggregate, Compressive Strength and Durability

\section{Introduction}

Concrete is an essential component in hydraulic construction projects all over the world. It is one of the elements that account for the highest cost in any construction project [1]. Annually, humankind consumes huge amounts of concrete resources and produces vast quantities of waste and pollution as a result of this consumption process [2]. However, for an effective utilization of concrete waste, it is necessary to use the recycled aggregate as concrete aggregate. The practical usage of the recycled aggregate concrete, produced by crushing concrete waste, reduces the consumption of natural aggregate. Using Portland cement in concrete contributes remarkably to greenhouse gas emissions. The total of annual emissions caused by cement production is estimated to be about 1.35 billion tons [3]. Geopolymer concrete is provided as one of the solutions formed by using source materials that contain both reactive silica $\left(\mathrm{SiO}_{2}\right)$ and alumina $\left(\mathrm{Al}_{2} \mathrm{O}_{3}\right)$ activated with alkali solutions. The source of these materials can be derived from low-cost substances or industrial wastes, such as metakaolin, fly ash, rice husk ash, and furnace slag [4] [5] [6] [7]. Geopolymers concrete can be characterized by high compressive strength, low shrinkage, good acid resistance, and good fire resistance [8] [9].

The permeability of geopolymer concrete affects its durability in salt water. This feature is the main factor for determining the durability of concrete in marine environment. Accordingly, denser concrete will lead destructive agents to penetrate and flow through the pores [10]. Yet, in sometimes, the chloride environment can increase the compressive strength of the geopolymer concrete [11]. It is important to mention that some previous studies stated that fly ash-based geopolymer concrete has better durability than Portland-based concrete in aggressive environment such as sulphate, acid, and fire [12] [13].

The current research examines the mechanical properties of hand-mixed based geopolymer concrete. It also studies the effect coarse recycled aggregates has on geopolymer concrete (RAGC) in different marine environment, in comparison to the properties of geopolymer concrete made with natural aggregate concrete (basalt). Furthermore, the research studies their effect on the properties of geopolymer concrete in different water environments; sea and tap water.

\section{Background}

In order to formulate a good GPC mix-design, it is essential to know the different factors that will affect the properties of fly ash/slag which are based on GPC.

\subsection{Aluminosilicate}

Fly ash (FA) is considered to be one of the main sources of silica $\left(\mathrm{SiO}_{2}\right)$ and 
alumina $\left(\mathrm{Al}_{2} \mathrm{O}_{3}\right)$ in GPC. Regarding ASTM C618, FA is classified based on its chemical composition, in which the main difference is the calcium amount [14] [15] [16]. Due to improved mechanical and microstructural properties, ground granulated blast furnace slag (GGBFS) becomes one of the most common components in geopolymer mortar and concrete [15]. However, adding GGBFS causes poor workability as a result to the higher viscosity [17]. A previous study shows that the significant improvement in both setting time and compressive strength can be obtained by adding ground granulated blast furnace slag in the mixtures [18].

\subsection{Alkaline Solution}

Alkaline solution is utilized to activate aluminosilicate base materials in order to obtain geopolymer concrete. For the alkali-activators, several choices are adopted. Silicate and aluminum silicate enrich the alkaline activator species in a notable way. Theoretically, as mentioned in reference[19], any alkali element can be used in geopolymerisation reactions; however, most of the studies have focused on the effect of sodium $\left(\mathrm{Na}^{+}\right)$and potassium $\left(\mathrm{K}^{+}\right)$ions [19]-[30].

The durability of structure started to decrease since the first year (2005), when research was conducted, and kept on increasing throughout 20 years of investigation. A previous research calculated the safety factor needed to obtain the structure's performance in sea water [31]. It was found that the protection of the structure has been declined gradually year by year. Reference [11] finds that geopolymer concrete that is cured in sea water provides a higher compressive strength than the other curing systems that employ fresh water and room temperature. Reference [32] shows that there is abundance of $\mathrm{Na}^{+}$in the surrounding area in salt water curing. It is probably that $\mathrm{Na}^{+}$as well as other cations $\left(\mathrm{Ca}^{2+}\right)$ in the sample are less exposed to leaching. These excess cations in the surrounding curing solution and in the sample will help to promote the mechanism's reaction and geopolymer formation.

\section{Materials and Experimental Techniques}

\subsection{Materials}

\subsubsection{Coarse Aggregate (C.A)}

The used coarse aggregate in this research are:

- Natural aggregate (Baslt);

- Recycled aggregate (crushed concrete, crushed marble and crushed ceramic). Well graded coarse aggregate was used with the maximum size of $19 \mathrm{~mm}$.

1) Natural aggregate (NCA)

The researcher used natural coarse aggregate as basalt; supplied from Elminia quarries. This coarse aggregate is characterized by a specific gravity 2.63 , Volume Weight $1.61\left(\mathrm{t} / \mathrm{m}^{3}\right)$, and Absorption $0.8 \%$ as shown in Figure 1.

2) Recycled coarse aggregate (RCA)

a) Crushed marble 


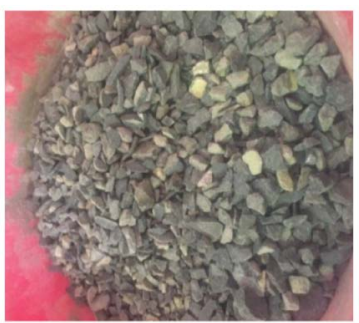

Basalt sample

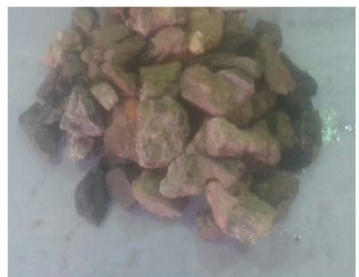

Crushed concrete sample

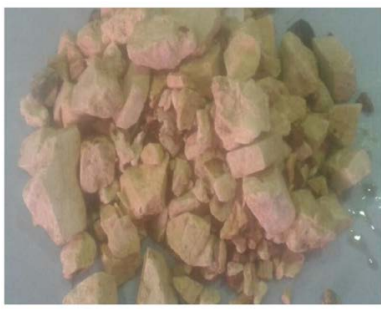

Crushed marble sample

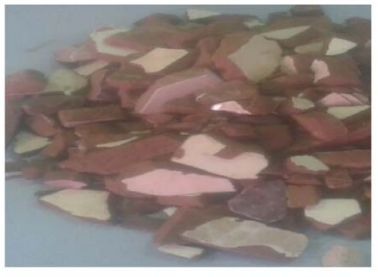

Crushed ceramic sample

Figure 1. Different types sample of aggregate.

The used crushed marble is supplied from residues of broken marble. It is of a specific gravity 2.62, Volume Weight $1.62\left(\mathrm{t} / \mathrm{m}^{3}\right)$, and Absorption $0.4 \%$. Table 1 shows the results of Sieve Analysis Test for crushed marble. And Table 1 shows the Chemical Composition of crushed marble.

b) Crushed concrete

The used crushed concrete is supplied from residues of ceramic factories. It is characterized by a specific gravity 2.5, Volume Weight $1.47\left(\mathrm{t} / \mathrm{m}^{3}\right)$, and Absorption $6.19 \%$.

c) Crushed ceramic

The used crushed ceramic in this study is supplied from residues of ceramic factories. The specific gravity of the crushed ceramic is 2.12, Volume Weight is $1.15\left(\mathrm{t} / \mathrm{m}^{3}\right)$ and Absorption is $10.62 \%$. Table 2 shows the chemical composition of crushed ceramic. Table 3 shows the results of Sieve Analysis Test for different types of aggregate while Figure 1 shows different types sample of the aggregate.

\subsubsection{Fine Aggregate (F.A)}

The used fine aggregate in this research was natural sand from 6 October quarries as shown in Figure 2. This fine aggregate's specific gravity is 2.55, Volume weight is $1.52\left(\mathrm{t} / \mathrm{m}^{3}\right)$, and Fineness modulus is 2.57 .

\subsubsection{Fly Ash}

Fly ash is a by-product which is the outcome of coal's combustion. Fly ash used in the study was low-calcium (ASTM Class F); dry fly ash brought from a factory in Sadat City-Egypt as shown in Figure 3. The specific gravity of the used fly ash is 1.9. Fly ashes are produced from bituminous and sub bituminous coals. They also contain alumina silicate glasses as active components. Figure 4 shows XRD of fly ash. This fly ash has a pozzolanic nature and contains less than $10 \%$ lime $(\mathrm{CaO})$. Table 4 summarizes the chemical structure of fly ash as per the manufacturer. 


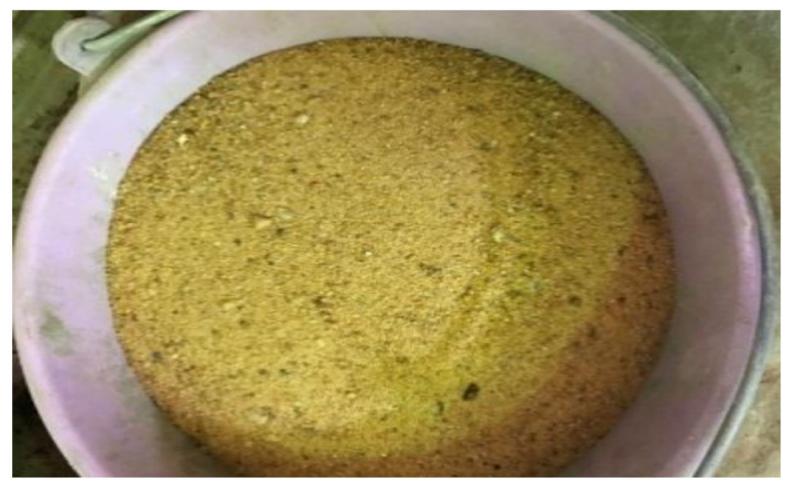

Figure 2. Sand sample.

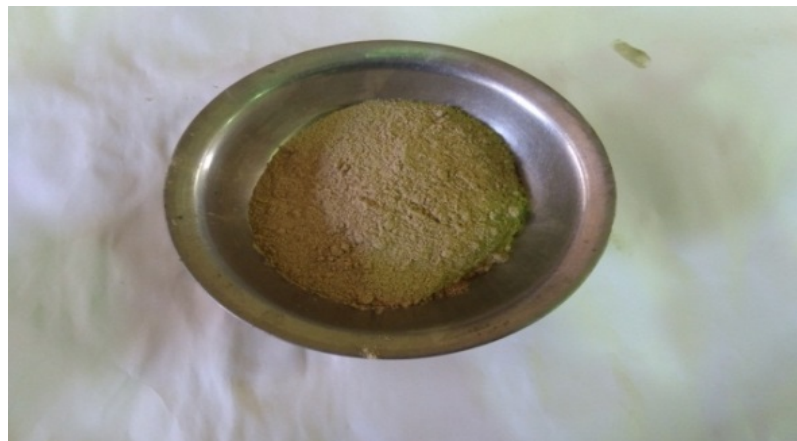

Figure 3. Fly ash sample.

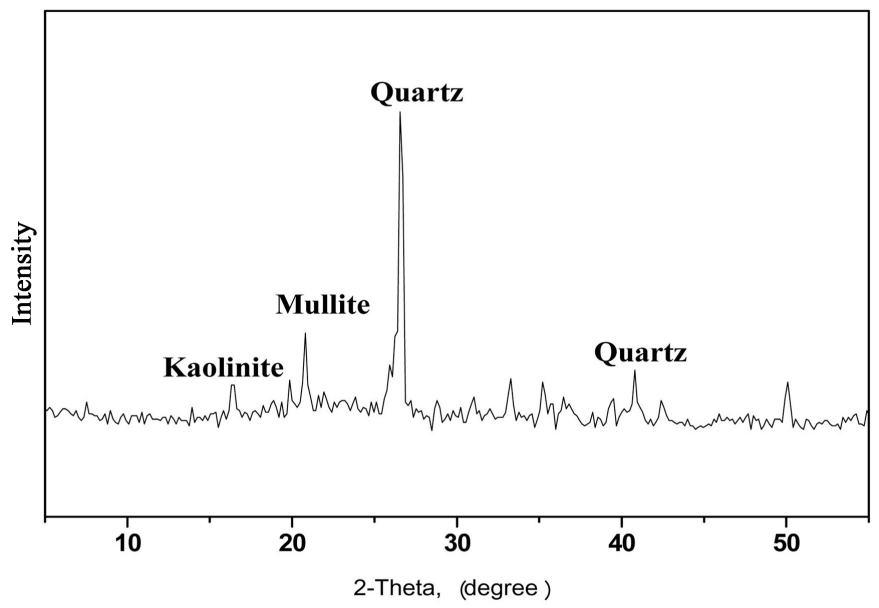

Figure 4. XRD of fly ash.

Table 1. Chemical composition of crushed marble.

\begin{tabular}{ccccccccc}
\hline Sample & $\mathrm{Fe}_{2} \mathrm{O}_{3}$ & $\mathrm{MnO}$ & $\mathrm{Na}_{2} \mathrm{O}$ & $\mathrm{MgO}$ & $\mathrm{K}_{2} \mathrm{O}$ & $\mathrm{Al}_{2} \mathrm{O}_{3}$ & $\mathrm{CaO}$ & $\mathrm{SiO}_{2}$ \\
\hline Crushed marble & 5.22 & 0.07 & 1.5 & 1.33 & 2.33 & 14.36 & 1.28 & 75.25 \\
\hline
\end{tabular}

Table 2. Chemical composition of crushed ceramic.

\begin{tabular}{cccccccccccc}
\hline Sample & $\mathrm{SiO}_{2}$ & $\mathrm{Al}_{2} \mathrm{O}_{3}$ & $\mathrm{Fe}_{2} \mathrm{O}_{3}$ & $\mathrm{CaO}$ & $\mathrm{MgO}$ & $\mathrm{SO}_{3}$ & $\mathrm{Na}_{2} \mathrm{O}$ & $\mathrm{K}_{2} \mathrm{O}$ & $\mathrm{TiO}_{2}$ & $\mathrm{MnO}$ & $\mathrm{P}_{2} \mathrm{O}_{5}$ \\
\hline Crushed ceramic & 54.97 & 14.28 & 4.77 & 11.14 & 3.36 & 2.07 & 1.27 & 3.08 & 0.55 & 0.06 & 0.17 \\
\hline
\end{tabular}


Table 3. Results of sieve analysis test for different types of aggregate.

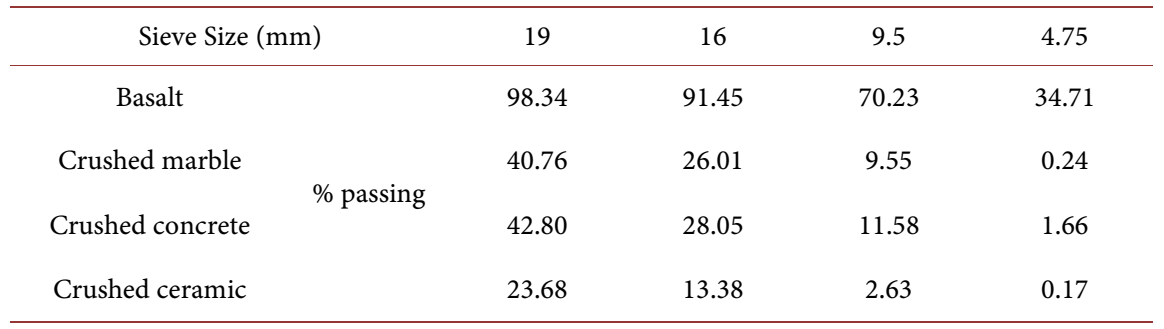

Table 4. Chemical composition of fly ash.

\begin{tabular}{ccccccccc}
\hline Sample & $\mathrm{SiO}_{2}$ & $\mathrm{Al}_{2} \mathrm{O}_{3}$ & $\mathrm{Fe}_{2} \mathrm{O}_{3}$ & $\mathrm{CaO}$ & $\mathrm{MgO}$ & $\mathrm{SO}_{3}$ & $\mathrm{Na}_{2} \mathrm{O}$ & $\mathrm{K}_{2} \mathrm{O}$ \\
\hline Fly Ash & 58.34 & 35.95 & 3.59 & 2.62 & 1.13 & 0.2 & 0.2 & 0.85 \\
\hline
\end{tabular}

\subsubsection{The Ground Granulated Blast Furnace Slag (GGBS)}

GGBFS is an industrial by-product which results from rapid water cooling of molten steel as shown in Figure 5. Ground granulated blast furnace slag materials have been composed of amorphous constituents. Figure 6 shows XRD of the slag. This material has favorable properties for cement industry as they are both relatively inexpensive and highly resistant to chemical attack. Table 5 shows the chemical composition of a slag with a specific gravity 3.2 that is available in Iron and Steel Factory and supplied from Helwan Governate.

\subsubsection{Activator Solution}

The utilized alkaline activator in this study was made as result of the combination of sodium silicate and sodium hydroxide solution. However, the activator that was made as a combination of the sodium silicate solution $\left(\mathrm{Na}_{2} \mathrm{O}=12.6 \%\right.$, $\mathrm{SiO}_{2}=29.39 \%$, water $=57 \%$ by mass $)$ and sodium hydroxide $(\mathrm{NaOH})$ in flakes or pellets-shape with $99 \%$ purity was prepared according to the reference.

\subsubsection{Super Plasticizer}

The current research used super plasticizer to reduce the early setting time of the concrete, the matter which in turn improves the mechanical behavior of GPC. For the work needs, the study used a high Range Water Reducing (HRWR) polymer-based super-plasticizer Naphthalene Sulfonate (BVS) that is supplied from CMB. Also, super plasticizers of $2 \%$ weight from binder were added. Table 6 shows the characteristics of the used admixture.

\subsection{Testing Method}

\subsubsection{Strengths Measurements}

The hardening of concrete was accessed from this test using cube specimens of $100 \times 100 \times 100 \mathrm{~mm}$ size. Figure 7 shows casting and testing of cube specimens ASTM: C109/C109M-13.

The research obtained the splitting tensile strength from the cylindrical specimen of diameter $150 \mathrm{~mm}$ and 300 height. Figure 8 shows the casting and testing of cylinder specimens [33]. 


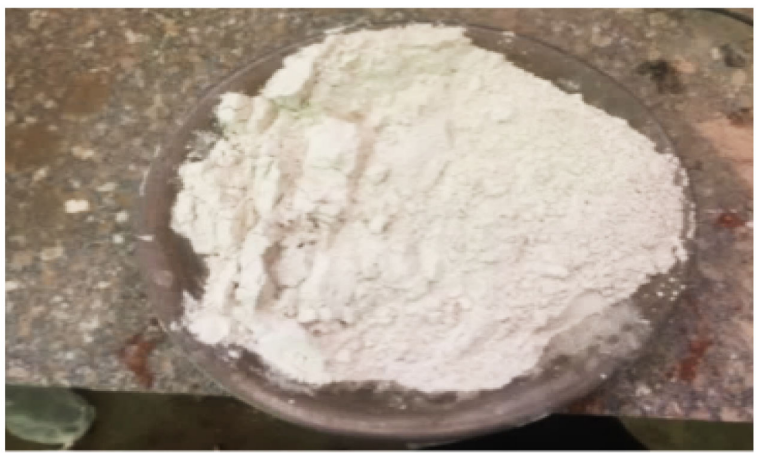

Figure 5. Ground granulated blast furnace slag sample.

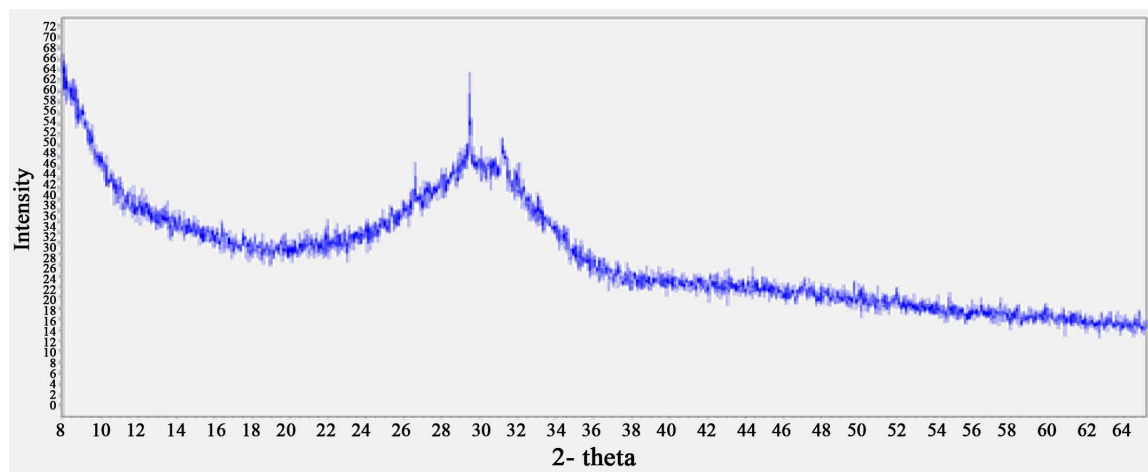

Figure 6. XRD of slag.

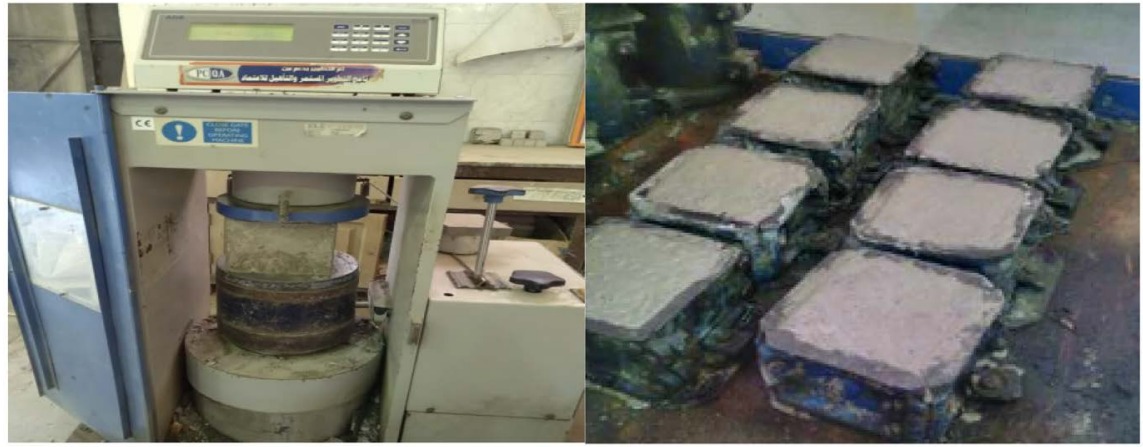

Figure 7. Casting and testing of cube specimens.

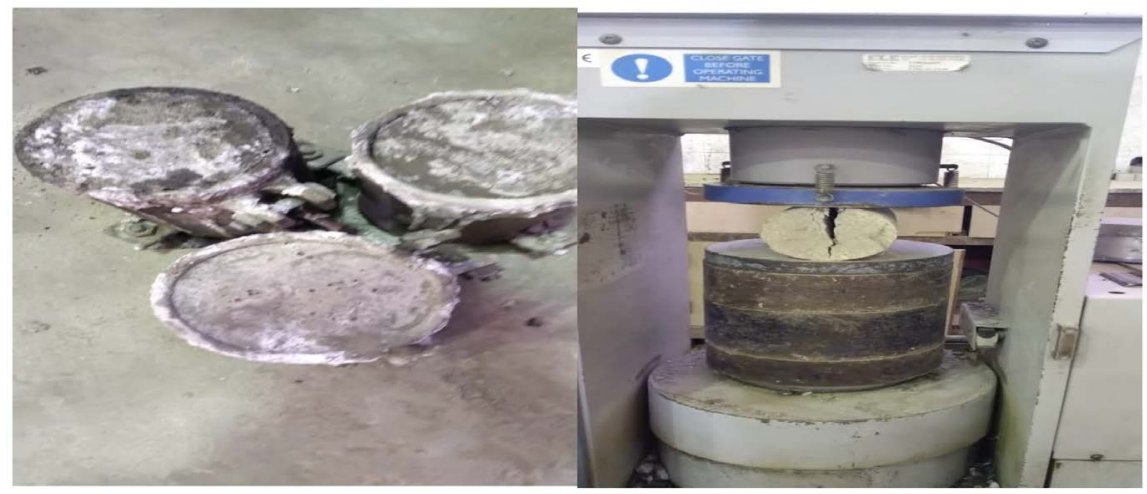

Figure 8. Casting and testing of cylinder specimens. 
Table 5. Chemical composition of slag.

\begin{tabular}{ccccccccc}
\hline Sample & $\mathrm{SiO}_{2}$ & $\mathrm{~A}_{12} \mathrm{O}_{3}$ & $\mathrm{Fe}_{2} \mathrm{O}_{3}$ & $\mathrm{CaO}$ & $\mathrm{MgO}$ & $\mathrm{SO}_{3}$ & $\mathrm{Na}_{2} \mathrm{O}$ & $\mathrm{K}_{2} \mathrm{O}$ \\
\hline Fly Ash & 37.83 & 10.4 & 0.48 & 34.44 & 4.47 & 1.61 & 0.93 & 0.43 \\
\hline
\end{tabular}

Table 6. Properties of superplasticizer.

\begin{tabular}{cc}
\hline Properties & Measured values \\
\hline Color & Brown \\
Specific gravity & 1.15 \\
Density (at $\left.20^{\circ} \mathrm{C}\right)$ & $1.2 \mathrm{~kg} /$ liter \\
Shelf life (month) & 12 \\
\hline
\end{tabular}

\subsubsection{Water Absorption}

Water absorption feature of geopolymer concrete plays a significate role for durability. The test was performed to evaluate the water absorption of geopolymer with different type of aggregate. In the test, the specimens of compressive strength and change in mass were $100 \times 100 \times 100 \mathrm{~mm}$ cubes of geopolymer concrete. Specimens for each test were prepared to change the mass average result of each specimen.

\section{Test Procedure}

The specimens that were used in the test were oven-dried at $1050^{\circ} \mathrm{C}$ for 24 hours. After the oven-drying, the specimens were immersed in water for another 24 hours. Absorption of geopolymer concrete with different aggregate was measured by evaluating the difference in weight of specimen after both the completion of the oven-drying process at $1050^{\circ} \mathrm{C}$, and immersion in water [34].

\subsubsection{Permeability of Geopolymer Concrete}

The specimens were tested with permeability machine as shown Figure 9. The specimens were placed in the apparatus and a water pressure of $(500 \pm 50) \mathrm{Kpa}$ was applied for 72 hours. The specimens were exposed to water pressure from one side after 28 days, then permeability factor and high water in side of the cupe were evaluated [35].

\subsubsection{X-Ray Diffraction (XRD)}

The present study adopted powder method of X-ray diffraction. For this method, a Philips diffractometer PW 1730 with X-ray source of $\mathrm{Cu} \mathrm{k} \alpha$ radiation $(\lambda$ $=1.5418 \AA$ ) was used. The scan step size was $2 \theta$, the collection time was $1 \mathrm{~s}$, and in the range $2 \theta$ from $5^{\circ} \mathrm{C}$ to $65^{\circ} \mathrm{C}$. The current and X-ray tube voltage were fixed at $40 \mathrm{KV}$ and $40 \mathrm{~mA}$ respectively [36].

\subsubsection{SEM Examinations}

The paste samples were examined by SEM to show the morphology of these materials. The Scanning Electron Microscope (SEM), model quanta 250 FEG (Field Emission Gun) are attached to EDX unit (Energy Dispersive X-ray Analyses), accelerating voltage of $30 \mathrm{KV}$. They are also with a magnification power $14 \times$ up 


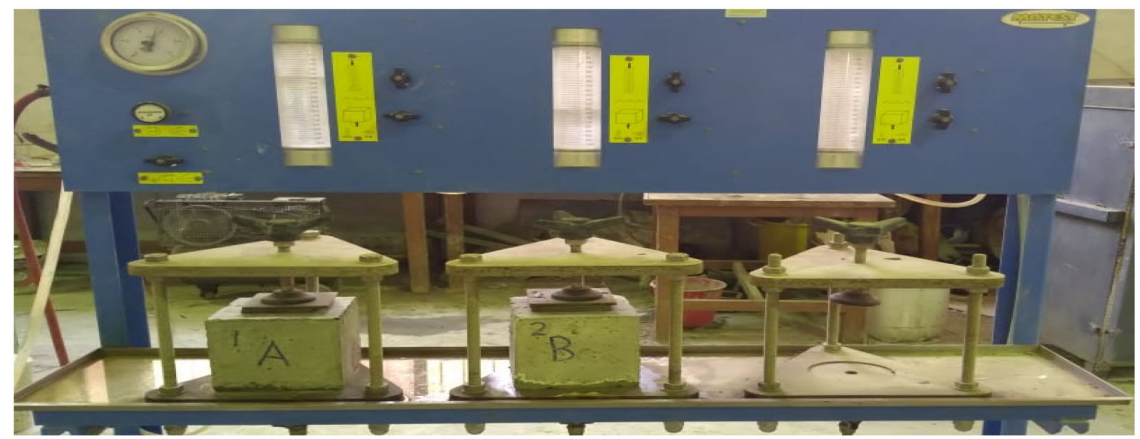

Figure 9. Permeability machine.

to $1,000,000$ and resolution for Gun.1n, FEI Company, Netherlands. To study the specimen's morphology without any coating, Backscattered electron detector (BSED) imaging was used [37].

\subsubsection{Near Infrared Spectroscopy IR}

Near Infrared Spectroscopy is a very sensitive tool for investigating the state of water in different systems. This tool is also used in cementing systems to investigate if hydration cements could pave the way for a future utilization in order to evaluate and compare this evolution among hydrating cementing systems. Therefore, the effect of additives on hydration kinetics can be estimated. Similarly, the quality of products can be examined. As this technique is regarded as an innovative one, other techniques have been used to compare and to confirm the effective validity of the results.

The NIR Spectrometer was a FT-MPA Bruker Optics; the reflection sphere sampling method was used to perform all the measurements. Specimens were prepared inapposite flat-bottomed glass vials; a weighed amount of cement was placed inside the vial. Then demineralized water was added with a pipette and mixed with a Vortexshaker. In order to guarantee a high reproducibility in the preparation of the samples, both mixing time and rate were kept constant for all the samples. Vials were then stored in a climatic room $\left(\mathrm{T}=20^{\circ} \mathrm{C}\right.$ and relative humidity [95\%]) to the point they reached the desired age. After that, the vial was broken and the cylinder-shaped cement sample was extracted. This sample was then cut in the middle and the NIR measurement was performed on the internal surface. All these precautions were taken so it would be possible to have a sample representative of the bulk of the specimen. Regarding the chemical tests, they were performed in National Research Center in Egypt [38] [39] [40] [41] [42].

\subsection{Curing Water}

Geopolymer concrete treatment was done using curing in potable water and sea water. The treatment lasted for 28 days, then an immersion in different water environments (potable water \& sea water from the Qaroun Fayoum Lake) took place. The chemical analysis of Qaroon Lake water is given in Table 7.

Mix properties 
Table 7. Chemical analysis of Qaron's lake water.

\begin{tabular}{cccc}
\hline Content & Quantity & Content & Quantity \\
\hline Density $\left(\mathrm{gm} / \mathrm{cm}^{3}\right)$ & 1.025 & Sulfates $(\mathrm{g} / \mathrm{l})$ & 9.712 \\
Soluble salts $(\mathrm{g} / \mathrm{l})$ & 35.438 & Chlorides $(\mathrm{g} / \mathrm{l})$ & 12.985 \\
Ions & - & Calcium ions $(\mathrm{g} / \mathrm{l})$ & 0.500 \\
Carbonates $(\mathrm{g} / \mathrm{l})$ & 0.030 & Magnesium $(\mathrm{g} / \mathrm{l})$ & 1.325 \\
Bicarbonates $(\mathrm{g} / \mathrm{l})$ & 0.305 & Sodium $(\mathrm{g} / \mathrm{l})$ & 10.109 \\
Others & 0.472 & & \\
\hline
\end{tabular}

Table 8 shows mixed properties, ratio that varies from sand to coarse aggregate (1:2). The table also shows $2 \%$ of super plastizer from total binder. The used alkaline activator has been formulated based on the combination of sodium silicate and sodium hydroxide solution. The laboratory experience stated that the ratio of sodium silicate solution-to-sodium hydroxide solution was taken as 2.33:1 by mass, $12 \mathrm{ml}$ concentration of Sodium hydroxide solution. Both fine aggregate and coarse aggregate were mixed and a small proportion of water, $10 \%$ of the cementitious material (fly ash), was added. Then the alkaline activator solution and fly ash were added to the wet mixture. For a proper bonding, the mixing lasted for 4 to 5 minutes. After the mixing took place, specimens were poured by giving the proper compaction. Four mixes were immersed in sea water (SW) and tab water (PW) for 60 days after curing. It was observed from the past studies that the quantity of the total binder was $450 \mathrm{~kg} / \mathrm{m}^{3}$ (80\% fly ash and $20 \%$ slag).

\section{Results and Discussion}

\subsection{Compressive Strength}

Table 9 and Figure 10 showed that geopolymer concrete used in crushed marble has a higher compressive strength than other mixes in salt water. Geopolymer concrete with basalt was used as a controlling specimen to compare its compressive strength with recycled aggregate geopolymer concrete. It is proved that salt water influences the strength of geopolymer concrete. Figure 10 points at the increases in compressive strength of geopolymer throughout 60 days when immersed in tab water. The figure also shows how this increasing behavior is reflected up throughout 90 days. For controlling the specimen at the 28th day, the compressive strength of the concrete was immersed in sea water, $46.3 \mathrm{~N} / \mathrm{mm}^{2}$, yet it increased drastically from $50.67 \mathrm{~N} / \mathrm{mm}^{2}$ on the 56 th day to $55.3 \mathrm{~N} / \mathrm{mm}^{2}$ on the 90th day.

According to the above, it is proved that the geopolymer concrete in sea water is more resistant than in tab water.

\subsection{Split Tensile Strengths}

Split tensile strengths for various mixes were obtained from the cylinder specimens 


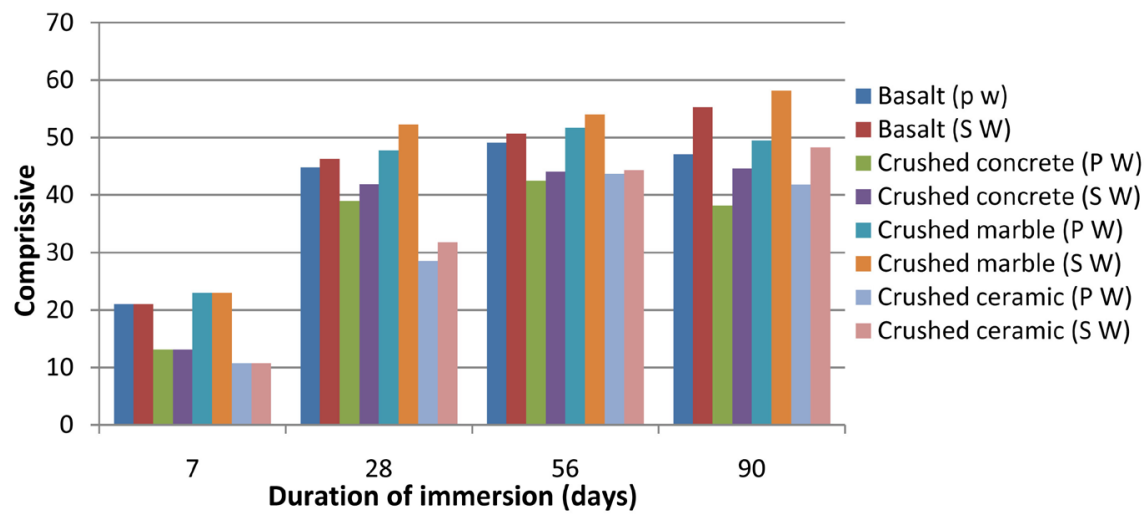

Figure 10. Comparison for compressive strength with different aggregate in geopolymer concrete with different water environments.

Table 8. Mix properties of different coarse aggregate in geopolymer concrete.

\begin{tabular}{ccccccccc}
\hline Mix & $\begin{array}{c}\text { Aggregate } \\
\text { type }\end{array}$ & $\begin{array}{c}\text { Fly ash } \\
\left(\mathrm{kg} / \mathrm{m}^{3}\right)\end{array}$ & $\begin{array}{c}\text { Slag } \\
\left(\mathrm{kg} / \mathrm{m}^{3}\right)\end{array}$ & $\begin{array}{c}\mathrm{CA} \\
\left(\mathrm{kg} / \mathrm{m}^{3}\right)\end{array}$ & $\begin{array}{c}\text { Fine } \\
\text { aggregate } \\
\left(\mathrm{kg} / \mathrm{m}^{3}\right)\end{array}$ & $\begin{array}{c}\text { Activator } \\
\text { solution } \\
(\text { ratio/binder })\end{array}$ & $\begin{array}{c}\text { Sodium } \\
\text { silicate } \\
\left(\mathrm{kg} / \mathrm{m}^{3}\right)\end{array}$ & $\begin{array}{c}\text { Sodium } \\
\text { hydroxide } \\
12 \mathrm{M}\left(\mathrm{kg} / \mathrm{m}^{3}\right)\end{array}$ \\
\hline M1 & Basalt & 360 & 90 & 1133.13 & 566.56 & 0.38 & 119.7 & 51.3 \\
M2 & $\begin{array}{c}\text { Crushed } \\
\text { concrete }\end{array}$ & 360 & 90 & 1081.94 & 540.97 & 0.4 & 126 & 54 \\
M3 & $\begin{array}{c}\text { Crushed } \\
\text { marble }\end{array}$ & 360 & 90 & 1133.63 & 566.8 & 0.37 & 116.55 & 49.95 \\
M4 & $\begin{array}{c}\text { Crushed } \\
\text { ceramic }\end{array}$ & 360 & 90 & 951.6 & 475.79 & 0.43 & 133 & 57 \\
\hline
\end{tabular}

Table 9. Compressive strength for different types of coarse aggregate in geopolymer concrete.

\begin{tabular}{|c|c|c|c|c|c|c|}
\hline \multirow[b]{2}{*}{ Mix sample } & \multirow{2}{*}{$\begin{array}{c}\text { Type of } \\
\text { aggregate }\end{array}$} & \multicolumn{4}{|c|}{ Compressive strength $\left(\mathrm{N} / \mathrm{mm}^{2}\right)$} & \multirow{2}{*}{$\begin{array}{c}\text { Type of } \\
\text { immersed water }\end{array}$} \\
\hline & & $\begin{array}{l}7 \text { Age } \\
\text { (days) }\end{array}$ & $\begin{array}{l}28 \text { Age } \\
\text { (days) }\end{array}$ & $\begin{array}{l}56 \text { Age } \\
\text { (days) }\end{array}$ & $\begin{array}{l}90 \text { Age } \\
\text { (days) }\end{array}$ & \\
\hline \multirow{2}{*}{ M1 } & \multirow{2}{*}{ Basalt } & 21.0 & 44.8 & 49.08 & 47.08 & potable water \\
\hline & & 21.0 & 46.3 & 50.67 & 55.3 & Sea water \\
\hline \multirow{2}{*}{ M2 } & \multirow{2}{*}{$\begin{array}{l}\text { Crushed } \\
\text { concrete }\end{array}$} & 13.1 & 39.0 & 42.5 & 38.17 & potable water \\
\hline & & 13.1 & 41.9 & 44.09 & 44.6 & Sea water \\
\hline \multirow{2}{*}{ M3 } & \multirow{2}{*}{$\begin{array}{l}\text { Crushed } \\
\text { marble }\end{array}$} & 23.0 & 47.8 & 51.7 & 49.5 & potable water \\
\hline & & 23.0 & 52.3 & 54.05 & 58.2 & Sea water \\
\hline \multirow{2}{*}{ M4 } & \multirow{2}{*}{$\begin{array}{l}\text { Crushed } \\
\text { ceramic }\end{array}$} & 10.7 & 28.5 & 43.7 & 41.8 & potable water \\
\hline & & 10.7 & 31.8 & 44.3 & 48.3 & Sea water \\
\hline
\end{tabular}

on the 28th day with a replacement of coarse aggregate. A similar trend like compressive strength was also noticed in case of the split tensile strength on the 28th day. Figure 11, Table 10 show that the used geopolymer concrete in crushed marble has higher split tensile strength than other mixes. Geopolymer 


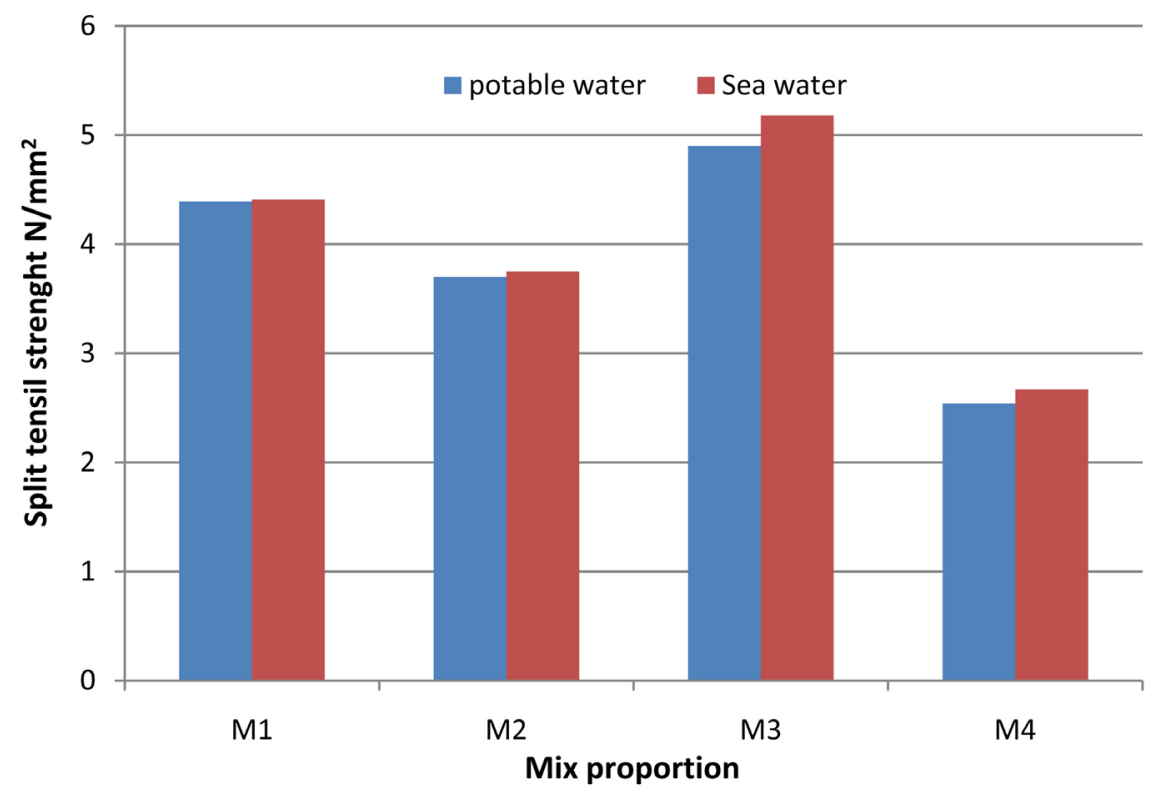

Figure 11. Comparison for split tensile strength with different aggregate in geopolymer concrete.

Table 10. Split tensile strength for different types of coarse aggregate in geopolymer concrete.

\begin{tabular}{cccc}
\hline Mix sample & Type of aggregate & Splitting tensile strength at 28 days $\left(\mathrm{N} / \mathrm{mm}^{2}\right)$ \\
\hline \multirow{2}{*}{ M1 } & Basalt & 4.39 & potable water \\
& & 4.41 & Sea water \\
M2 & Crushed concrete & 3.7 & potable water \\
& & 3.75 & Sea water \\
M3 & Crushed marble & 4.9 & potable water \\
& & 5.18 & Sea water \\
M4 & Crushed ceramic & 2.54 & potable water \\
& & 2.67 & Sea water \\
\hline
\end{tabular}

concrete with basalt that was used as a controlling specimen recorded 4.39 $\mathrm{N} / \mathrm{mm}^{2}$ to compare its split tensile strengths with recycled aggregate geopolymer concrete which was increased by $15.7 \%$ and $42.1 \%$ for both crushed concrete and crushed ceramic, and decreased by $11.62 \%$ for crushed marble which curing by potable water.

\subsection{Mineralogical Composition}

\subsubsection{Scanning Electron Microscopy for Different Coarse Aggregate (SEM)}

The SEM-photographs and digital photos of geopolymers are displayed in Figure 12. Figures (a)-(c) obviously show SEM at two magnification scales as well as $(5 \& 50 \mu)$ digital photos of crushed concrete, crushed marble and crushed ceramic (from top to bottom). The SEM-photographs and digital photos showed that the pores' content and sizes decrease with marble content and W/CA ratio. 

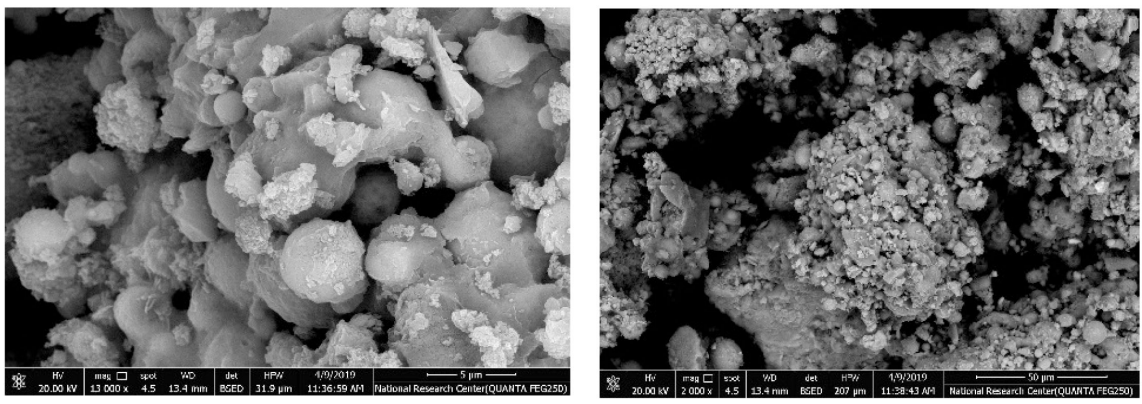

(a)
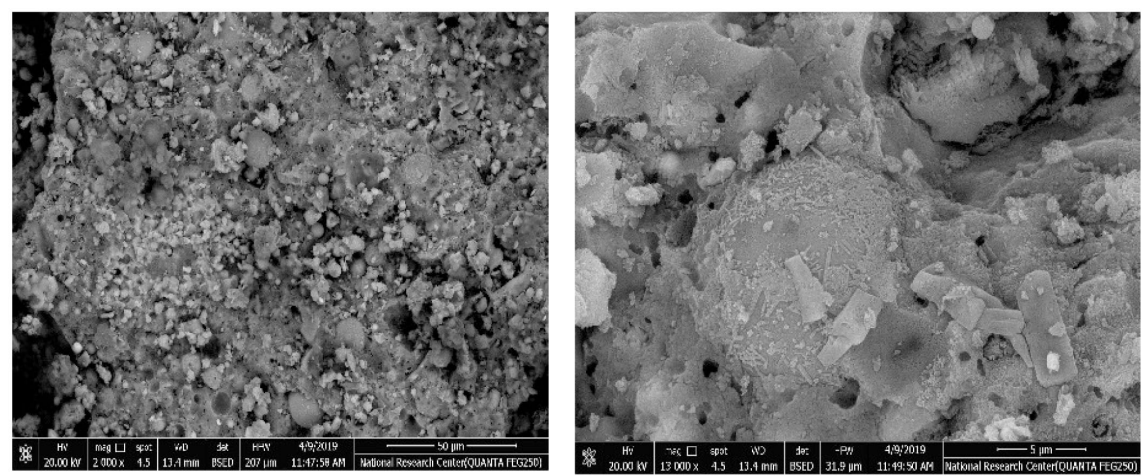

(b)
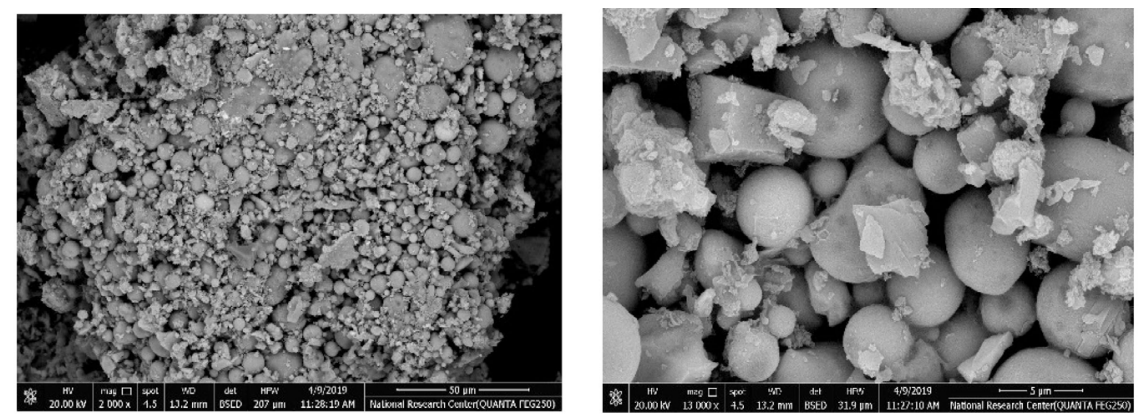

(c)

Figure 12. SEM-photographs and digital photos of different aggregate of geopolymers. (a) Crushed concrete; (b) Crushed marble; (c) Crushed ceramic.

It was observed that pores' size in ceramic and concrete is large compared to marble due to the high level of microstructure formation. Accordingly, both the positive impact of chemical compassion of marble with fly ash and slag, and the enhancement of pores formation were confirmed. The results of compressive strength, porosity, and SEM-photographs are harmonious with each other. From ecological science perspective, the used technique in this work is a $\mathrm{CO}_{2}$ emission-free technique. Also, in this work, geopolymer binder is used as main precursor in the production of thermally insulating materials instead of Portland cement (which strongly contributes in global warming Potential).

\subsubsection{Microstructure of Different Aggregate Base Geopolymer (Infrared Analysis (IR))}

Figure 13 showed the near-, mid-, and far-infrared (IR) spectra of synthetic, 


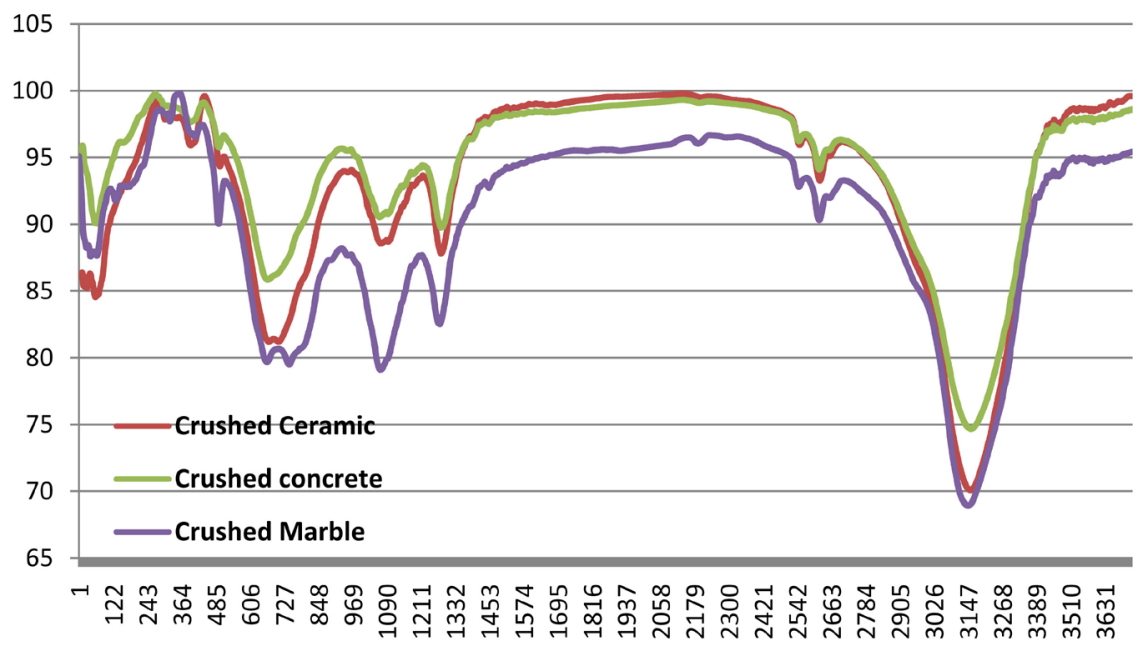

Figure 13. IR spectra of fly ash and slag based geopolymer with different coarse aggregate.

single-phase calcium silicate hydrate (C-S-H) were analyzed to study the structure of the hydrates and provide new significant insights into their $\mathrm{H}_{2} \mathrm{O}$ and $\mathrm{OH}$ environments. The $\mathrm{C}-\mathrm{S}-\mathrm{H}$ had $\mathrm{Ca} / \mathrm{Si}(\mathrm{C} / \mathrm{S})$ ratios of $0.41-1.85,1.4 \mathrm{~nm}$ tobermorite, $1.1 \mathrm{~nm}$ tobermorite, and jennite. The main mid-IR bands occurred at 950 1100, 810 - 830, $660-670$, and $440-450 / \mathrm{cm}$ consistent with single silicate chain structure. In the near-IR region, the combination band at $4567 / \mathrm{cm}$ due to $\mathrm{Si}-\mathrm{OH}$ stretching plus $\mathrm{O}-\mathrm{H}$ stretching decreased in intensity and was absent at $\mathrm{C} / \mathrm{S}$ greater than approximately 1.2. In the far-IR region, the C-S-H samples with $\mathrm{C} / \mathrm{S}$ greater than approximately 1.3 increased the absorption intensity at approximately $300 / \mathrm{cm}$.

The mid-, close to-, and some distance-infrared (IR) spectra of synthetic, single-phase calcium silicate hydrates $(\mathrm{C}-\mathrm{S}-\mathrm{H})$ with $\mathrm{Ca} / \mathrm{Si}$ ratios $(\mathrm{C} / \mathrm{S})$ of 0 . Forty one-1.85, $1.4 \mathrm{~nm}$ tobermorite, $1.1 \mathrm{~nm}$ tobermorite, and jennite confirm the similarity of the structure of these phases and provide vital new perception into their $\mathrm{H}_{2} \mathrm{O}$ and $\mathrm{OH}$ environments. The predominant mid-IR bands arise at 950 $1100,810-830,660-670$, and $440-450 \mathrm{~cm}^{-1}$, consistent with unmarried silicate chain systems. For the C-S-H samples, the mid-IR bands trade systematically with increasing $\mathrm{C} / \mathrm{S}$ ratio, regular with reducing silicate polymerization and with an increasing content material of jennite-like structural environments of $\mathrm{C} / \mathrm{S}$ ratios $>1.2$. The $950-1100 \mathrm{~cm}^{-1}$ institution of bands due to Si-O stretching shifts first to decrease wave quantity due to reducing polymerization after which to higher wave numbers, in Figure 13, it is proven that the beaten marble shits to better wave wide variety and lower choices compared by way of crushed ceramic and concrete because of extra polymerization in marble. The $660-670 \mathrm{~cm}^{-1}$ band due to Si-O-Si bending broadens and reduces in depth for samples regular with depolymerization and decreased structural order in figure shown that the beaten marble decrease choices as compared by means of overwhelmed ceramic and urban due to more polymerization and increases in depth of marble. 
The close to-, mid-, and some distance-infrared (IR) spectra of synthetic, provide the idea for a greater whole structural version for this form of C-S-H, that is defined calcium silicate hydrate (C-S-H) have been analyzed to have a look at the shape of the hydrates and offer new big insights into their $\mathrm{H}_{2} \mathrm{O}$ and $\mathrm{OH}$ environments. The C-S-H had $\mathrm{Ca} / \mathrm{Si}(\mathrm{C} / \mathrm{S})$ ratios of $0.41-1$. The major mid-IR bands befell at $950-1100,810-830,660-670$, and $440-450 / \mathrm{cm}$ regular with single silicate chain structure. In the close to-IR region, due to Si-OH stretching plus $\mathrm{O}-\mathrm{H}$ stretching decreased in depth in the long way-IR location, the $\mathrm{C}-\mathrm{S}-\mathrm{H}$ samples accelerated the absorption intensity at approximately three hundred $/ \mathrm{cm}$. That indicted the marble is extra polymerization more than other concrete [38] [39] [40] [41] [42].

\subsubsection{X-Ray Diffraction XRD}

The X-ray diffraction XRD was used to study the transformation in crystallinityof geopolymer source materials (GSMs) after treatment with distinctive amounts of sodium silicate Figure 14. At the day 28, XRD patterns show the presence of the primary materials of the beginning raw material which includes calcite, quartz, and mullite in addition to hydration products and an amorphous geopolymer. For the geopolymer end products, the large hump shows that there is amorphous geopolymer shaped. An extensive hump between $18^{\circ}$ and $36^{\circ} 2 \theta$ is the representative form of amorphous geopolymers. Regarding the length of the extensive hump between $18^{\circ}$ and $36^{\circ} 2 \theta$ for Marble, there may be a growth in the length of the extensive hump in case of blend which comprises Marble that is similar to the formation of hydration product which includes C-S-H (Calcium silicate hydrate). The presence of C-S-H improves the mechanical houses. These results match previous effects received from compressive strength.

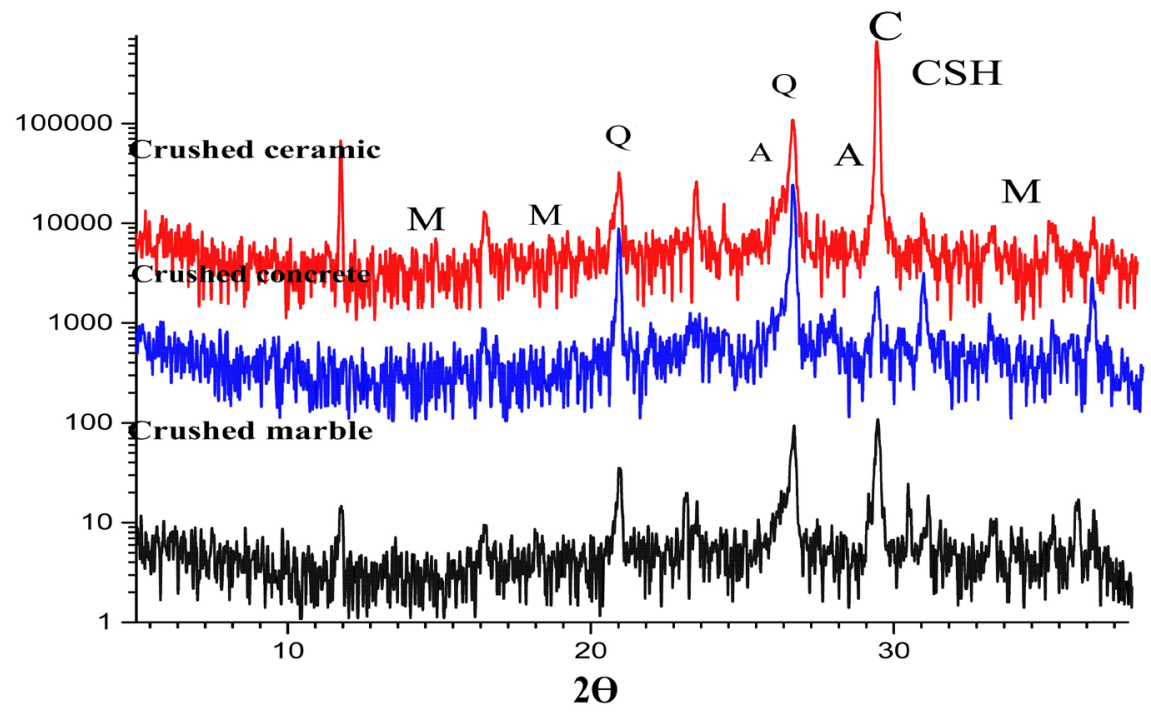

Figure 14. XRD patterns for the starting raw material at 28 days (M: Mullite, Q: Quartz, A: Amorphous geopolymer, C: Calcite, C-S-H: Calcium silicate hydrate). 


\subsection{Permeability of Geopolymer Concrete with Different Aggregate}

In this examination, to study the permeability of geopolymer concrete with different types of aggregate, four different samples were prepared; basalt, crushed concrete, crushed marble and crushed ceramic respectively. Figure 15 demonstrates the permeability factor of geopolymer concrete with basalt concrete which was $0.605 \times 10^{-6}$, yet decreased by $25.6 \%$ and $131.4 \%$ for crushed concrete and crushed ceramic; however, it increased by $14.9 \%$ for crushed marble as shown in Table 11. Figure 16 shows High of water in all samples, Figure 17 shows permeability sample with different types of aggregate.

To calculate permeability factor let parameter in equation:

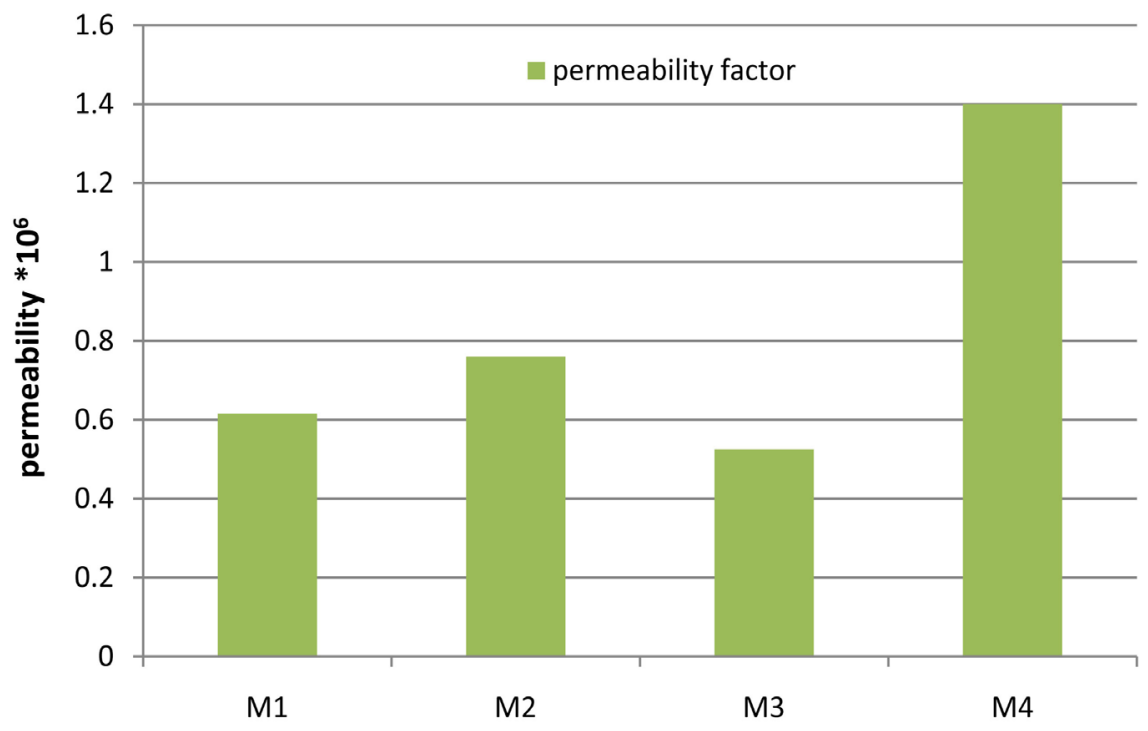

Figure 15. Permeability of all samples.

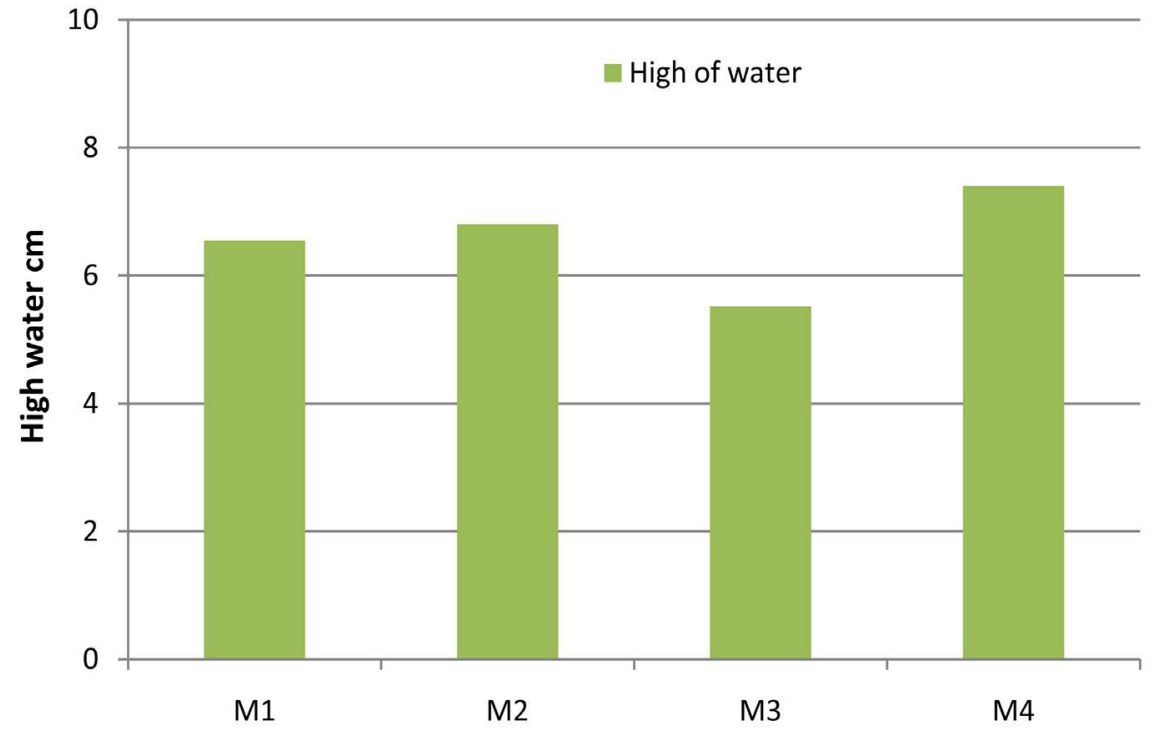

Figure 16. High of water in all samples. 


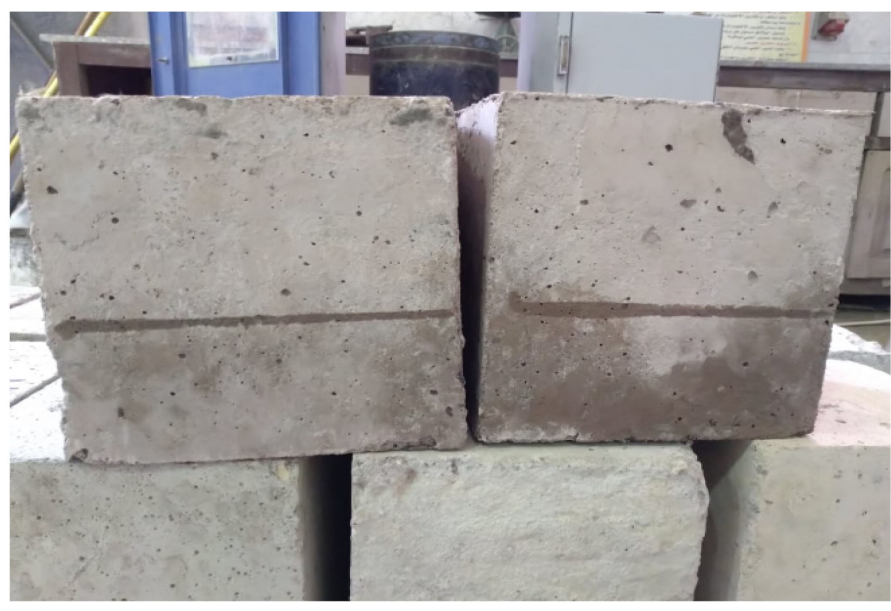

Figure 17. Permeability sample with different type of aggregate.

Table 11. Permeability factor for sample with different type of aggregate.

\begin{tabular}{cccccc}
\hline Mix sample & $\begin{array}{c}\text { Type of } \\
\text { aggregate }\end{array}$ & Notation & $\begin{array}{c}\text { Water high of } \\
\text { sample cm }\end{array}$ & $\begin{array}{c}\text { Permeability } \\
\text { factor mm/s }\end{array}$ & $\begin{array}{c}\text { Standard } \\
\text { classification }\end{array}$ \\
\hline M1 & Basalt & M1-1 & 6.3 & $0.59 \times 10^{-6}$ & impermeability \\
M2 & $\begin{array}{c}\text { Crushed } \\
\text { concrete }\end{array}$ & M2-1 & 6.5 & $0.62 \times 10^{-6}$ & \\
& M2-2 & 7.1 & $0.77 \times 10^{-6}$ & impermeability \\
M3 & $\begin{array}{c}\text { Crushed } \\
\text { marble }\end{array}$ & M3-1 & 5.23 & $0.51 \times 10^{-6}$ & impermeability \\
& M3-2 & 5.81 & $0.52 \times 10^{-6}$ & \\
M4 & $\begin{array}{c}\text { Crushed } \\
\text { ceramic }\end{array}$ & M4-1 & 7.1 & $0.10 \times 10^{-5}$ & low permeability \\
\hline
\end{tabular}

$$
\text { permeability factor }=\frac{C c \times H}{T \times A \times P} \mathrm{~mm} / \mathrm{s}
$$

where:

$C c$ volume of water in pipe customization throw $72 \mathrm{hr} \cdot \mathrm{cm}^{3}$;

$H$ : high of sample;

$T$ : time by second;

$A$ : area exposes to water pressure;

$P$ : water pressure by $\mathrm{cm}(5-6)$ bar;

For basalt geopolymer concrete:

Sample M1-1:

$$
\begin{aligned}
\text { permeability factor }(\mathrm{K} 1) \text { for } & =\frac{1370 \times 15 \times 10}{225 \times 72 \times 60 \times 60 \times 6 \times 1000} \\
& =0.59 \times 10^{-6} \mathrm{~mm} / \mathrm{s}
\end{aligned}
$$

where:

Cc. $1370 \mathrm{~cm}^{3}, H: 15 \mathrm{~cm}, A: 15 \times 15 \mathrm{~cm}^{2}, T: 72 \mathrm{hr}, P: 6$ bar $(5-6)$ bar;

Sample M1-2: 


$$
\begin{aligned}
\text { permeability factor }(\mathrm{K} 1) \text { for } & =\frac{1450 \times 15 \times 10}{225 \times 72 \times 60 \times 60 \times 6 \times 1000} \\
& =0.62 \times 10^{-6} \mathrm{~mm} / \mathrm{s}
\end{aligned}
$$

where:

Cc. $1450 \mathrm{~cm}^{3}, H: 15 \mathrm{~cm}, A: 15 \times 15 \mathrm{~cm}^{2}$, T: 72 hr., P: 6 bar (5 - 6) bar.

For crushed concrete geopolymer concrete:

Sample M2-1:

$$
\begin{aligned}
\text { permeability factor }(\mathrm{K} 2) & =\frac{1750 \times 15 \times 10}{225 \times 72 \times 60 \times 60 \times 6 \times 1000} \\
& =0.75 \times 10^{-6} \mathrm{~mm} / \mathrm{s}
\end{aligned}
$$

where:

Cc. $1750 \mathrm{~cm}^{3}, H: 15 \mathrm{~cm}, A: 15 \times 15 \mathrm{~cm}^{2}$, T: $72 \mathrm{hr}, P: 6$ bar $(5-6)$ bar. Sample M2-2:

$$
\begin{aligned}
\text { permeability factor }(\mathrm{K} 2) & =\frac{1800 \times 15 \times 10}{225 \times 72 \times 60 \times 60 \times 6 \times 1000} \\
& =0.77 \times 10^{-6} \mathrm{~mm} / \mathrm{s}
\end{aligned}
$$

where:

Cc. $1800 \mathrm{~cm}^{3}, H: 15 \mathrm{~cm}, A: 15 \times 15 \mathrm{~cm}^{2}, T: 72 \mathrm{hr}, P: 6$ bar $(5-6)$ bar. For crushed marble geopolymer concrete:

Sample M3-1:

$$
\begin{aligned}
\text { permeability factor }(\mathrm{K} 3) & =\frac{1190 \times 15 \times 10}{225 \times 72 \times 60 \times 60 \times 6 \times 1000} \\
& =0.51 \times 10^{-6} \mathrm{~mm} / \mathrm{s}
\end{aligned}
$$

where:

Cc. $1190 \mathrm{~cm}^{3}, H: 15 \mathrm{~cm}, A: 15 \times 15 \mathrm{~cm}^{2}, T: 72 \mathrm{hr}, P: 6$ bar $(5-6)$ bar. Sample M3-2:

$$
\begin{aligned}
\text { permeability factor }(\mathrm{K} 3) & =\frac{1210 \times 15 \times 10}{225 \times 72 \times 60 \times 60 \times 6 \times 1000} \\
& =0.52 \times 10^{-6} \mathrm{~mm} / \mathrm{s}
\end{aligned}
$$

where:

Cc. $1210 \mathrm{~cm}^{3}, H: 15 \mathrm{~cm}, A: 15 \times 15 \mathrm{~cm}^{2}, T: 72 \mathrm{hr}, P: 6$ bar (5 - 6) bar. For crushed ceramic geopolymer concrete:

Sample M4-1:

$$
\begin{aligned}
\text { permeability factor }(\mathrm{K} 4) & =\frac{2430 \times 15 \times 10}{225 \times 72 \times 60 \times 60 \times 6 \times 1000} \\
& =0.10 \times 10^{-5} \mathrm{~mm} / \mathrm{s}
\end{aligned}
$$

where:

C. $2430 \mathrm{~cm}^{3}, H: 15 \mathrm{~cm} . A: 15 \times 15 \mathrm{~cm}^{2}$, T: $72 \mathrm{hr}, P: 6$ bar $(5-6)$ bar. Sample M4-2:

$$
\begin{aligned}
\text { permeability factor }(\mathrm{K} 4) & =\frac{2750 \times 15 \times 10}{225 \times 72 \times 60 \times 60 \times 6 \times 1000} \\
& =0.18 \times 10^{-5} \mathrm{~mm} / \mathrm{s}
\end{aligned}
$$


where:

Cc. $2750 \mathrm{~cm}^{3}, H: 15 \mathrm{~cm} . A: 15 \times 15 \mathrm{~cm}^{2}$, T: $72 \mathrm{hr} ., P: 6$ bar (5 - 6) bar.

\subsection{Absorption Percentage of Geopolymer Concrete with Different Types of Aggregate}

Water absorption of the geopolymer concrete plays an important role for the durability of the structure. Ingress of water deteriorates concrete and in reinforced concrete structure. Table 12 shows Weight before sub-margin, Weight after submerge in water for 24 hours. The result demonstrates that water absorption of geopolymer concrete with basalt aggregate was, $45 \%$, then decreased by $11.1 \%$ and $44.4 \%$ for crushed concrete and crushed ceramic. It also increased by 21.11 for crushed marble as shown in Table 12, Figure 18.

$$
\% \text { absorption }=\frac{\mathrm{W} 2-\mathrm{W} 1}{\mathrm{~W} 1}
$$

where:

W1: Weight before sub-margin; W2: Weight after submerge for $24 \mathrm{hr}$.

\section{For basalt geopolymer concrete:}

Sample M1-1:

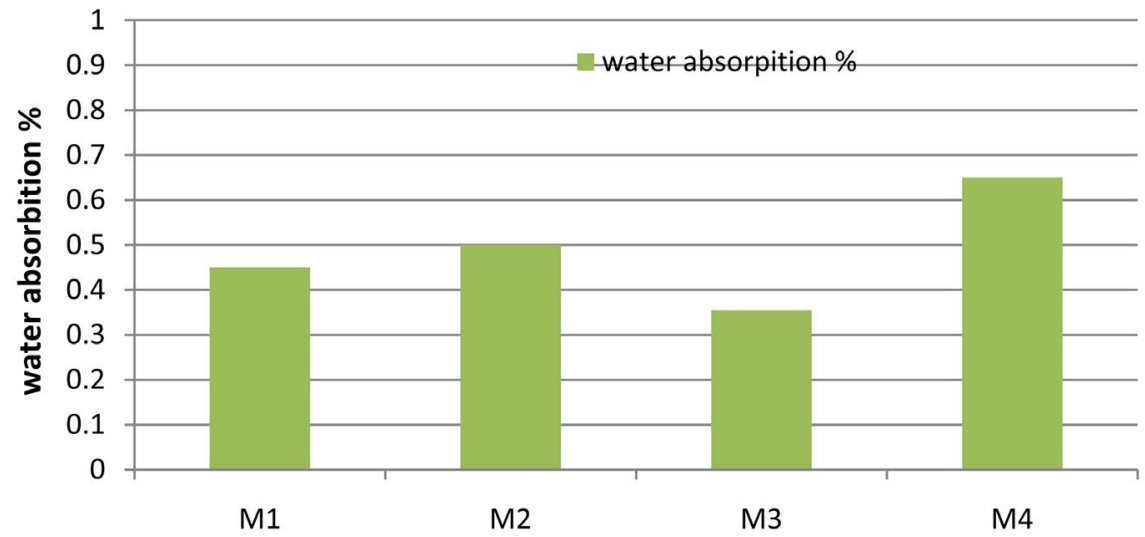

Figure 18. Water absorption of geopolymer concrete with different aggregate.

Table 12. Mix samples for absorption.

\begin{tabular}{ccccc}
\hline Type of aggregate & Notation & $\begin{array}{c}\text { Weight before } \\
\text { Submargin (W1) }\end{array}$ & $\begin{array}{c}\text { Weight after } \\
\text { Submargin (W2) }\end{array}$ & \% absorption \\
\hline \multirow{2}{*}{ Basalt } & M1-1 & 8.495 & 8.532 & $0.44 \%$ \\
& M1-2 & 8.499 & 8.538 & $0.46 \%$ \\
Crushed concrete & M2-1 & 8.348 & 8.391 & $0.52 \%$ \\
& M2-2 & 8.275 & 8.315 & $0.48 \%$ \\
Crushed marble & M3-1 & 8.873 & 8.905 & $0.36 \%$ \\
& M3-2 & 8.899 & 8.930 & $0.35 \%$ \\
Crushed ceramic & M4-1 & 8.136 & 8.190 & $0.66 \%$ \\
& M4-2 & 8.168 & 8.220 & $0.64 \%$ \\
\hline
\end{tabular}




$$
\% \text { absorption }=\frac{8.532-8.495}{8.495}=0.44 \%
$$

Sample M1-2:

$$
\% \text { absorption }=\frac{8.538-8.499}{8.499}=0.46 \%
$$

For crushed concrete geopolymer concrete:

Sample M2-1:

$$
\% \text { absorption }=\frac{8.391-8.348}{8.348}=0.52 \%
$$

Sample M2-2:

$$
\% \text { absorption }=\frac{8.315-8.275}{8.275}=0.48 \%
$$

\section{For crushed marble geopolymer concrete:}

Sample M3-1:

$$
\% \text { absorption }=\frac{8.905-8.873}{8.873}=0.36 \%
$$

Sample M3-2:

$$
\% \text { absorption }=\frac{8.930-8.899}{8.899}=0.35 \%
$$

For crushed ceramic geopolymer concrete:

Sample M4-1:

$$
\% \text { absorption }=\frac{8.190-8.136}{8.136}=0.66 \%
$$

Sample M4-2:

$$
\% \text { absorption }=\frac{8.220-8.168}{8.168}=0.64 \%
$$

\section{Conclusions}

This experimental study examined the impact of sea water on recycled coarse aggregate, which is obtained from the materials' waste, on both hardness and durability of the geopolymer concrete. Main conclusions derived based on the present study could be summarized as follows:

1) Geopolymer concrete in salt water has higher compressive strength than geopolymer concrete in potable water. This matter proves that geopolymer concrete is durable in marine environment since there is abundance of $\mathrm{Na}^{+}$in sea water. The maximum value of compressive strength at 90 days for geopolymer concrete utilized crushed marble in salt water increased percentage than geopolymer concrete utilized crushed marble in potable water by $14.86 \%$.

2) Geopolymer concrete reaches its strength at higher rate in early stages (7 days age), and reaches a ratio of about 55 to $65 \%$ of the compressive strength at 28 days. 
3) Geopolymer concrete utilized in crushed marble has higher compressive strength than other mixes, increasing percentage by $5 \%, 23,37 \%$ and $17 \%$ for basalt, crushed concrete and crushed ceramic .

4) The presence of sodium in crushed ceramic improves compressive strength.

5) Permeability and water absorption for geopolymer concrete with marble have better durability than other mixes.

6) Geopolymer concrete with crushed marble has an excellent quality in hydraulic buildings and buildings under water such as dams, tanks, channels, pier and bridges.

\section{Conflicts of Interest}

The authors declare no conflicts of interest regarding the publication of this paper.

\section{References}

[1] Maharashtra, W. (2017) Productivity of Batching Plant and Quality of Concrete Production. Sudeshna Wawhal PG Scholar, Department of Civil Engineering, Imperial College of Engineering and Research, India. https://www.ijariit.com/manuscripts/v3i1/V3I1-1137.pdf

[2] Pacheco-Torgal, F., Jalali, S., Labrincha, J. and John, V.M. (2013) Eco-Efficient Concrete. In: Wood Head Publishing Series in Civil and Structural, Elsevier, ¡Amsterdam, Netherlands.

https://www.elsevier.com/books/eco-efficient-concrete/pacheco-torgal/978-0-85709 $\underline{-424-7}$

https://doi.org/10.1533/9780857098993

[3] Malhotra, V.M. (2002) Introduction: Sustainable Development and Concrete Technology. ACI Concrete International, 24, 22.

https://www.concrete.org/publications/internationalconcreteabstractsportal.aspx?m $=$ details $\& I D=12127$

[4] Deb, P.S., Nath, P. and Sarker, P.K. (2014) The Effects of Ground Granulated Blast-Furnace Slag Blending with Fly Ash and Activator Content on the Workability and Strength Properties of Geopolymer Concrete Cured at Ambient Temperature. Materials and Design, 62, 32-39.

https://espace.curtin.edu.au/handle/20.500.11937/6084

[5] Duxson, P., Fernández-Jiménez, A., Provis, J.L., Lukey, G.C., Palomo, A. and van Deventer, J.S.J. (2007) Geopolymer Technology: The Current State of the Art. Journal of Materials Science, 42, 2917-2933.

https://www.scirp.org/(S(351jmbntvnsjt1aadkposzje))/reference/ReferencesPapers.a spx?ReferenceID $=1190223$ https://doi.org/10.1007/s10853-006-0637-z

[6] Majidi, B. (2009) Geopolymer Technology, from Fundamentals to Advanced Applications: A Review. Materials \& Design, 24, 79-87. https://www.tandfonline.com/doi/abs/10.1179/175355509X449355 https://doi.org/10.1179/175355509X449355

[7] Posi, P., et al. (2013) Lightweight Geopolymer Concrete Containing Aggregate from Recycle Lightweight Block. Materials \& Design, 52, 580-586.

https://projecteuclid.org/euclid.aos/1369836961 
https://doi.org/10.1016/j.matdes.2013.06.001

[8] Davidovits, J. (1991) Geopolymers: Inorganic Polymeric New Materials. Journal of Thermal Analysis, 37, 1633-1656. https://www.scirp.org/

https://doi.org/10.1007/BF01912193

[9] Davidovits, J. (1994) Properties of Geopolymer Cements. In: Proceedings of First International Conference on Alkaline Cements and Concretes, Scientific Research Institute on Binders and Materials, VIPOL Stock Company, Ukraine, 131-149. https://www.geopolymer.org/fichiers_pdf/KIEV.pdf

[10] Reddy, D.V., Edouard, J.B., Sobhan, K. and Rajpathak, S.S. (2011) The Influence of Salt Water on Chloride Penetration in Geopolymer Concrete.

https://cyberleninka.org/article/n/736167

[11] Bayuaji, R., Dharmawan, M.S., Wibowo, B., Husin, N.A., Subektie, S. and Ekaputri, J.J. (2015) The Influence of Chloride Environment on Compressive Strength of Geopolymer Concrete with Fly Ash Using Taguchi Approach. Mechanics of Materials, 754-755, 400-405. https://www.scientific.net

[12] Chindaprasirt, P. and Chalee, W. (2014) Effect of Sodium Hydroxide Concentration on Chloride Penetration and Steel Corrosion of Fly Ash-Based Geopolymer Concrete under Marine Site. Construction and Building Materials, 63, 303-310. https://doi.org/10.1016/j.conbuildmat.2014.04.010

[13] Singh, N., Vyass, S., Pathak, R.P., Sharma, P., Mahure, N.V. and Gupta, S.L. (2013) The Influence of Salt Water on Chloride Penetration in Geopolymer Concrete. International Journal of Innovations in Engineering and Technology, 3, 2277.

[14] Diaz, E.I., Allouche, E.N. and Eklund, S. (2010) Factors Affecting the Suitability of Fly Ash as Source Material for Geopolymers. Fuel, 89, 992-996. https://doi.org/10.1016/j.fuel.2009.09.012

[15] Nath, P. and Sarker, P.K. (2014) Effect of GGBFS on Setting, Workability and Early Strength Properties of Fly Ash Geopolymer Concrete Cured in Ambient Condition. Construction and Building Materials, 66, 163-171. https://doi.org/10.1016/j.conbuildmat.2014.05.080

[16] Rashad, A.M. (2014) A Comprehensive Overview about the Influence of Different Admixtures and Additives on the Properties of Alkali-Activated Fly Ash. Materials \& Design, 53, 1005-1025. https://doi.org/10.1016/j.matdes.2013.07.074

[17] Kumar, S., Kumar, R. and Mehrotra, S.P. (2010) Influence of Granulated Blast Furnace Slag on the Reaction, Structure and Properties of Fly Ash Based Geopolymer. Journal of Materials Science, 45, 607-615. https://doi.org/10.1007/s10853-009-3934-5

[18] Saha, S. and Rajasekaran, C. (2017) Enhancement of the Properties of Fly Ash Based Geopolymer Paste by Incorporating Ground Granulated Blast Furnace Slag. Construction and Building Materials, 146, 615-620.

https://www.sciencedirect.com/science/article/abs/pii/S0950061817307729 https://doi.org/10.1016/j.conbuildmat.2017.04.139

[19] Fan, F. (2015) Mechanical and Thermal Properties of Fly Ash-Based Geopolymer Cement. Master of Science, Civil and Environmental Engineering, Baton Rouge, LA.

[20] Xu, H. and Van Deventer, J.S.J. (2000) The Geopolymerisation of Alumino-Silicate Minerals. International Journal of Mineral Processing, 59, 247-266. https://doi.org/10.1016/S0301-7516(99)00074-5

[21] Xu, H. and Van Deventer, J.S.J. (1999) The Geopolymerisation of Natural Alumino-Silicates. In: Proceedings of the 2 nd International Conference on Geopolymer, Saint Qunentin, France, 43-64. 
[22] The Brick Industry Association (2006) Technical Notes on Brick Construction (Manufacturing of Brick). The Brick Industry Association, Reston, VA.

[23] Monteiro, S.N., Vieira, C.M.F. and de Carvalho, E.A. (2005) Technological Behavior of Red Ceramics Incorporated with Brick Waste. Revista Materia, 10, 537-542.

[24] Shakhashiri, P. (2003) Lime: Calcium Oxide-CaO. Scifun Chemical of the Week.

[25] Yip, C.K. and Van Deventer, J.S.J. (2001) Effect of Granulated Blast Furnace Slag on Geopolymerisation. CD-ROM Proceedings 6 th World Congress of Chemical Engineering, Melbourne, Australia, 23-27 September 2001.

[26] Yip, C.K., Lukey, G.C. and Van Deventer, J.S.J. (2005) The Coexistence of Geopolymeric Gel and Calcium Silicate Hydrate at the Early Stage of Alkaline Activation. Cement and Concrete Research, 35, 1688-1697. https://doi.org/10.1016/j.cemconres.2004.10.042

[27] Xu, H. and Van Deventer, J.S.J. (2002) Microstructural Characterisation of Geopolymers Synthesized from Kaolinite/Stilbite Mixtures Using XRD, MAS-NMR, SEM/EDX, TEM/EDX and HREM. Cement and Concrete Research, 32, 1705-1716. https://doi.org/10.1016/S0008-8846(02)00859-1

[28] Lee, W.K. (2002) Solid-Gel Interactions in Geopolymers. Ph.D. Thesis, Department of Chemical Engineering, University of Melbourne, Australia.

[29] De Silva, P., Sagoe-Crenstil, K. and Sirivivatnanon, V. (2007) Kinetics of Geopolymerization: Role of $\mathrm{Al}_{2} \mathrm{O}_{3}$ and $\mathrm{SiO}_{2}$. Cement and Concrete Research, 37, 521-518. https://doi.org/10.1016/j.cemconres.2007.01.003

[30] Van Jaarsveld, S. and Van Deventer, J.S.J. (1999) Effect of the Alkali Metal Activator on the Properties of Fly-Ash Based Geopolymers. Industrial and Engineering Chemistry Research, 38, 3932-3941. https://doi.org/10.1021/ie980804b

[31] Ekaputri, J.J. and Triwulan (2008) Remaining Useful Life (RUL) of Onshore Structure in East Kalimantan, Indonesia. Proceedings 4th International Conference on Forensic Engineering. https://www.researchgate.net/ https://doi.org/10.1680/fefftu.36130.0029

[32] Giasuddin, H.M., Sanjayan, J.G. and Ranjith, P.G. (2013) Strength of Geopolymer Cured in Saline Water in Ambient Conditions. Fuel, 107, 34-39.

https://www.researchgate.net https://doi.org/10.1016/j.fuel.2013.01.035

[33] ASTM C496/C496-M-11 (2017) Standard Test Method for Splitting Tensile Strength of Cylindrical Concrete Specimens. ASTM International, West Conshohocken, PA. https://www.astm.org

[34] ASTM Standard C642 (2006) Standard Test Method for Density, Absorption, and Voids in Hardened Concrete. ASTM International, West Conshohocken, PA.

https://www.astm.org https://doi.org/10.1520/C0642-06

[35] British Standard BS EN 12390-8 (2009) Testing Hardened Concrete Part 8: Depth of Penetration of Water under Pressure.

[36] Guo, X.L., Shi, H.S. and Dick, W.A. (2010) Compressive Strength and Microstructural Characteristics of Class C Fly Ash Geopolymer. Cement and Concrete Composites, 32, 142-147. https://doi.org/10.1016/j.cemconcomp.2009.11.003

[37] Sayed, M. and Zeedan, S.R.K. (2012) Green Binding Material Using Alkali Activated Blast Furnace Slag with Silica Fume. HBRC Journal, 8, 117-184. https://doi.org/10.1016/j.hbrcj.2012.10.003

[38] Ridi, F., Fratini, E., Dilani, S. and Baglioni, P. (2006) Near-Infrared Spectroscopy 
Investigation of the Water Confined in Tricalcium Silicate Pastes. The Journal of Physical Chemistry B, 110, 16326-16331. https://doi.org/10.1021/jp060026y

[39] Gastaldi, D., Canonico, F. and Boccaleri, E. (2009) Ettringite and Calcium Sulfoaluminate Cement: Investigation of Water Content by Near-Infrared Spectroscopy. Journal of Materials Science, 44, 5788-5794.

https://doi.org/10.1007/s10853-009-3812-1

[40] Yu, P., Kirkpatrick, R.J., Poe, B., McMillan, P.F. and Cong, X. (1999) Structure of Calcium Silicate Hydrate (C-S-H): Near-, Mid-, and Far-Infrared Spectroscopy. Journal of the American Ceramic Society, 82, 742-748. https://doi.org/10.1111/j.1151-2916.1999.tb01826.x

[41] Bacchiorini, A. and Guilhot, B. (1982) Premieres echeances de l'hydratation de l'aluminate monocalcique influence du protocole de stoppage. Cement and Concrete Research, 12, 559-567. https://doi.org/10.1016/0008-8846(82)90016-3

[42] Giangiacomo, R. (2006) Study of Water-Sugar Interactions at Increasing Sugar Concentration by NIR Spectroscopy. Food Chemistry, 96, 371-379.

https://doi.org/10.1016/j.foodchem.2005.02.051 